\title{
MODEL PENINGKATAN DAYA SAING PETANI DENGAN PENDEKATAN KOPERASI AGRIBISNIS DI KOTA MEDAN
}

\author{
Sri Endang Rahayu dan Mailina Harahap \\ Fakultas Pertanian \\ Universitas Muhammadiyah sumatera Utara \\ Email. meilina@umsu.ac.id
}

\begin{abstract}
Abstrak
Potensi pertanian di Kecamatan Marelan meskipun dalam skala usaha kecil yang dikelola oleh rumahtangga petani, perlu untuk dikembangkan. Apabila petani memiliki daya saing tinggi maka tingkat pendapatan petani akan meningkat. Sehingga diperlukan sebuah wadah yang mendorong petani untuk lebih meningkatkan produktifitasnya dalam rangka menghasilkan produk yang memiliki daya saing. Disamping itu perlu adanya jaminan pasar yang memberikan tingkat harga menguntungkan bagi petani. Koperasi merupakan salah satu alternatif dalam menyikapi lemahnya akses petani pada berbagai sumberdaya produktif, yaitu modal, teknologi dan informasi pasar.Penelitian ditujukan untuk merumuskan model peningkatan daya saing petani dengan pendekatan koperasi agribisnis. Sampel penelitian adalah petani sayur mayur di Kecamatan Medan Marelan yang diambil secara purposive sampling. Data yang diperoleh diolah dengan menggunakan analisis deskriptif, analisis SWOT dan analisis The House Model. Model peningkatan daya saing petani sayur dapat dilaksanakan dengan memperhatikan aspek faktor internal dan eksternal yang selanjutnya dapat ditetapkan sebuah visi dalam peningkatan daya saing petani yaitu; "Dengan Koperasi Agribisnis Petani Produktif dan Berdaya Saing". Adapun aspek yang perlu dilaksanakan untuk mewujudkan visi tersebut adalah aspek komoditi sayur petani, aspek kelembagaan dan aspek komunitas.
\end{abstract}

Kata kunci: Daya saing petanisayur, struktur rantai pasok, kelembagaan rantai pasok dan koperasi agribisnis.

\section{A. PENDAHULUAN}

Tahun 2003 Indonesia memiliki 31,17 juta rumahtangga petani sedangkan pada tahun 2013 rumahtangga petani berjumlah 26,13 juta, dengan demikian terdapat penurunan 5,04 juta rumahtangga petani. (BPS. 2014).Penurunan jumlah rumahtangga petani akan memperburuk sektor pertanian. Dan secara langsung akan berimplikasi pada pertumbuhan ekonomi. Maka sangat diperlukan perhatian terhadap keberlanjutan sektor pertanian. Salah satu aspek penting adalah merangsang peran serta petani dalam menggerakkan koperasi yang berorientasi terhadap sistem agribisnis. Sebagaimana dikemukakan oleh Hanafie (2010) bahwa koperasi masih belum sepenuhnya mampu memanfaatkan kegiatan agribisnis dari hulu ke hilir, yang sesungguhnya memiliki nilai tambah lebih besar. Peran dan fungsi koperasi untuk meningkatkan perekonomian masyarakat khususnya petani belum optimal. Mekanisme koperasi belum dikembangkan secara efisien dan kurang tanggap terhadap berbagai perubahan.

Pemerintah kota Medan menetapkan suatu kawasan agribisnis pada sebahagian wilayah kota Medan yaitu bagian Utara kota Medan mencakup wilayah kecamatan Medan Labuhan, Medan Deli dan Medan Marelan. Bagian Selatan mencakup Kecamatan Medan Amplas, Bagian wilayah Barat mencakup Kecamatan Medan Tuntungan dan Medan Selayang dan bagian wilayah Timur mencakup Kecamatan Medan Sunggal dan Kecamatan Medan Helvetia. (BPS. 2013)

Kecamatan Medan Marelan merupakan salah satu sentra tanaman sayur di kota Medan yang memiliki potensi besar untuk dikembangkan. Sebagaimana Sony Batubara (2014) mengemukakan bahwa produksi sayur mayur yang dihasilkan petani di Kota Medan mencapai 50 ton yang sebagian besar diproduksi petani Medan Marelan.(http://mdn.biz.id/). Hasil komoditi petani sayur kecamatan Marelan antara lain; sawi manis, terong ungu, bayam, kangkung, kailan, pak choy, dan lain sebagainya. Dalam perkembangannya hasil panen petani sayur Kecamatan Marelan di pasarkan ke pasar tradisional oleh petani sendiri dan juga melalui agen hingga ke konsumen akhir.

Potensi pertanian di Kecamatan Marelan meskipun dalam skala usaha kecil yang dikelola oleh rumahtangga petani, perlu untuk dikembangkan. Apabila petani memiliki daya saing tinggi maka tingkat pendapatan petani akan meningkat. Sehingga diperlukan sebuah wadah yang mendorong petani untuk lebih meningkatkan produktifitasnya dalam rangka menghasilkan produk yang memiliki daya saing. Disamping itu perlu adanya jaminan pasar yang memberikan tingkat harga menguntungkan bagi petani. Koperasi merupakan salah satu alternatif dalam menyikapi lemahnya akses petani pada berbagai sumberdaya produktif, yaitu modal, teknologi dan informasi pasar. Peluang pasar yang menjanjikan diharapkan 
mampu memberikan dorongan pada petani untuk lebih meningkatkan produksi dengan melakukan intensifikasi pertanian dengan produk yang memiliki daya saing dan penguatan kelembagaan petani.

Keberadaan koperasi akan meningkatkan aktivitas ekonomi petani dengan saling menguatkan dalam menghasilkan produk yang memiliki daya saing tinggi. Dengan koperasi yang berbasis pada agribisnis akan mendorong kemajuan ekonomi petani dengan semakin mudahnya akses terhadap modal, teknologi dan pasar. Wijaya. S (2002) mengungkapkan, manfaat berkoperasi: 1) membantu meningkatkan standar sosial ekonomi di daerah dengan memanfaatkan potensi dan penyerapan tenaga kerja; 2) bermanfaat langsung, karena sesuai dengan kehidupan masyarakat pedesaan; dan 3) ekonomi pedesan bisa tumbuh karena koperasi berakar kuat di pedesaan.Pada akhirnya akan meningkatkan pendapatan petani yang lebih baik dengan mampu menghasilkan unit usaha pertanian unggulan dan potensi unggulan yang diharapkan sebagai sektor pendorong kemajuan wilayah.

\section{B. METODE PENELITIAN}

Jenis dan Desain Penelitian

Penelitian yang akan dilakukan adalah jenis penelitian survey dengan memperhatikan kondisi sosial ekonomi petani sayur Kecamatan Medan Marelan. Adapun desain penelitian dirancang adalah desain penelitian pengembangan (development research) yang akan dilakukan secara bertahap dalam waktu dua (2) tahun.

\section{Lokasi Penelitian}

Jenis penelitian yang dilakukan adalah penelitian kasus dengan mengambil lokasi penelitian di Kecamatan Medan Marelan Kota Medan Provinsi Sumatera Utara. Adapun penentuan lokasi didasarkan pada bahwa kecamatan Medan Marelan memiliki potensi cukup besar sebagai penghasil sayur mayur di Kota Medan.

Jenis Data Penelitian dan Teknik Pengumpulan Data

Jenis data penelitian menggunakan data primer dan data sekunder. Data primer diperoleh dengan metode wawancara dengan menggunakan panduan wawancara(interview guide)dan dilakukan juga wawancara mendalam (indepth interview) terhadap responden. Sementara data sekunder diperoleh dari instansi-instansi dan referensi terkait dengan penelitian.

Sampel Penelitian dan Teknik pengambilan sampel Populasi penelitian adalah petani sayur yang terdapat di Kecamatan Medan Marelan Kota
Medan. Adapun sampel penelitian yang digunakan dalam penelitian berjumlah 40 orang petani sayur. Teknik pengambilan sampel dilakukan secara purposive sampling yang merupakan metode pengambilan sampel dimana peneliti memiliki kriteria atau tujuan tertentu terhadap sampel yang akan diteliti.

\section{Metode Analisis}

Adapun analisis yang digunakan pada penelitian adalah;

Untuk menganalisis berbagai aspek yang diperlukan untuk memperoleh model peningkatan daya saing petani sayur dengan pendekatan agribisnis dilakukan dengan pendekatan analisis SWOT. Hasil analisis dari identifikasi kondisi problematis petani sayur akan digunakan untuk mengidentifikasi faktor internal dan faktor eksternal pada analisis SWOT tersebut. Selanjutnya hasil dari analisis SWOT digunakan untuk merumuskan visi dan pondasi dalam menciptakan suatu konsep perwujudan tindakan nyata melalui The House Model yang dapat dijadikan suatu acuan untuk peningkatan daya saing petani sayur di Kecamatan Medan Marelan.

\section{HASIL DAN PEMBAHASAN}

Kelembagaan Pada Rantai Pasok Sayur Kecamatan Medan Marelan.

Kelembagaan memilki peran penting untuk meningkatkan daya saing petani yang pada akhirnya akan berimplikasi pada peningkatan taraf hidup petani. Pada kegiatan usaha tani sayur, aspek kelembagaan tidak terlepas dari kegiatan pertanian yang berorientasi pada pasar. Sebagaimana Hanafie (2010) mengemukakan bahwa aspek kelembagaan antara lain adalah pasar yang berfungsi untuk membeli sarana produksi pertanian dan menjual hasil pertanian, pelayanan penyuluhan untuk menerapkan teknologi baru, dan lembaga perkreditan.

Menurut Uphoff (1986), pola kelembagaan kemitraan dalam suatu masyarakat terdiri atas tiga pilar utama, yaitu kelembagaan pemerintah/public (public sector) kelembagaan komunitas (voluntary sector) dan kelembagaan ekonomi/pasar (private sector). Untuk mengkaji kelembagaan rantai pasok petani sayur Kecamatan Medan Marelan, menggunakan kelembagaan tiga pilar tersebut, yaitu; 1). Kelembagaan pemerintah yang terdiri dari dinas pertanian Kota Medan dan Badan Penyuluhan Pertanian Kota Medan, 2). Kelembagaan Komunitas yang terdiri dari petani sayur, kelompok tani dan pengumpul (agen sayur), 3). Kelembagaan Ekonomi/Pasar yang terdiri dari Lembaga Keuangan. 
Struktur rantai pasok komoditi sayur petani Kecamatan Medan Marelan dapat ditunjukkan pada gambar 1.

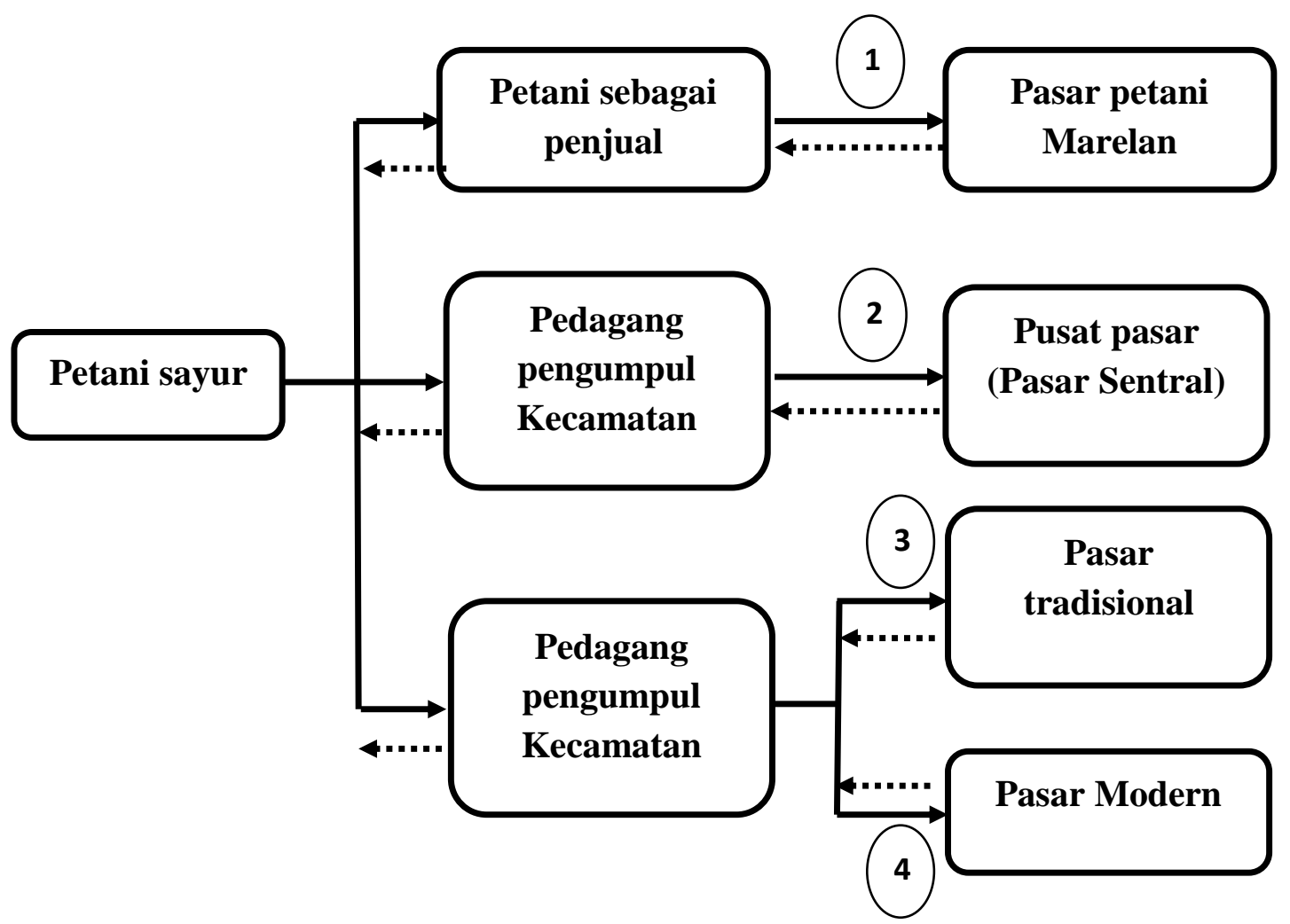

Gambar 1. Struktur rantai pasok sayur petani Kecamatan Medan Marelan

\section{Keterangan gambar :}

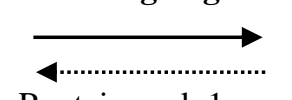

Rantai pasok 1

Rantai pasok 2

Rantai pasok 3

Rantai pasok 4

\section{Struktur rantai pasok 1}

Pada rantai pasok I pihal yang terlibat adalah petani sayur secara langsung. Hal ini dodorong oleh memperoleh pendapatan yang tinggi dari kegiatan usaha tani adalah tujuan petani. Untuk memperoleh tujuan tersebut, pada umumnya petani yang memiliki luas lahan dengan skala kecil menjual langsung hasil panen mereka pada pasar sayur yang terdapat di Pasar II Marelan. Dengan menjual sendiri, seperti jenis sayur Bayam dan Kangkung, petani memperoleh pendapatan yang lebih besar dari pada jika di pasarkan melalui agen.

\section{Struktur rantai pasok 2}

Pada struktur rantai pasok 2, sayuran hasil penen petani dibeli oleh pedagang pengumpul Kecamatan (agen) yang datang langsung ke lokasi usaha tani sayur. Sayur-sayur yang di distribusikan ke agen tersebut, tidak mengalami sortiran. Masing- masing petani memiliki langganan dengan pedagang pengumpul Kecamatan. Biasanya pedagang pengumpul bisa melihat kualitas dari sayur petani. Adapun sayur-sayur yang selanjutnya akan di bawa langsung ke pasar Sentral tidak di kemas secara khusus. Sayur Kangkung dan Bayam di jual kepada agen dengan jumlah satuan bal. Satu bal sayuran dapat di bagi lagi menjadi 10 ikatan. Pada umumnya agen sayur setelah melakukan transaksi dengan petani, langsung membagi 1 bal Bayam dan Kangkung menjadi 10 ikatan. Adapun biaya muat sayuran, pengangkutan dan biaya transportasi di tanggung oleh agen. Sayur-sayur yang diangkut dengan menggunakan kendaraan pick up tersebut selanjutnya di bawa ke pasar Sentral. Adapun pembeli yang menerima sayur petani di pasar Sentral adalah petani grosir yang akan menjual kembali sayur petani ke pasar-pasar sekitar Kota Medan. 


\section{Rantai pasok 3}

Pada rantai pasok 3, terdapat sedikit perbedaan dengan rantai pasok 2. Pada rantai pasok 3, sayur yang didistribusikan kepada pedagang pengumpul kecamatan (agen) selanjutnya di didistribusikan ke pasar-pasar tradisional sekitar kota Medan. Dengan demikian, sayur tidak lagi masuk ke pasar Sentral yang merupakan pusat pasar di Kota Medan. Disamping itu pada rantai pasok 3, keuntungan agen lebih besar daripada rantai pasok 2. Hal ini disebabkan Agen yang membawa sayur ke pasar tradisional kota Medan seperti pasar Brayan, Pasar Mabar, Pasar Pancing, Pasar Laut Dendang dan sebagainya tidak menjual sayur ke penjual grosir, tapi langsung ke penjual-penjual sayur di pasar. Biaya muat barang dan biaya transportasi di tanggung oleh agen.

\section{Rantai Pasok 4.}

Permintaan konsumen pada konsumsi sayur tidak hanya pada pasar tradisional. Perkembangan cara hidup masyarakat khususnya masyarakat kota, mendorong tersedianya sayur-sayuran pada pasar modern. Efisiensi dan ekonomis menjadi salah satu faktor masyarakat, melakukan berbelanja pada pasar modern. Sehingga kegiatan belanja menjadi satu kesatuan untuk berbelanja kebutuhan rumahtangga lainnya. Hal ini menjadi peluang petani untuk meningkatkan pendapatannya. Tetapi sangat disayangkan petani tidak memiliki akses terhadap pasar modern. Agen melakukan perlakuan yang berbeda terhadap komoditi sayur yang akan di pasarkan pada pasar tradisional dan pasar Modern. Pada pasar modern, agen melakukan pengemasan sayur-sayur (packaging) yang lebih rapi untuk selanjutnya di bawa ke pedagang grosir sayur khusus sayur yang memenuhi persayaratan untuk masuk pada pasar Modern.

\section{Analisis Faktor Internal dan Faktor Eksternal Usaha tani Sayur Kecamatan Medan Marelan.}

Berdasarkan rantai pasok yang menggambarkan kegiatan agribisnis petani sayur Kecamatan Medan Marelan, maka peningkatan daya saing petani sayur dapat dilakukan dengan pendekatan koperasi agribisnis. Untuk menemukan model peningkatan daya saing petani tersebut, digunakan analisis SWOT. Analisis SWOT merupakan salah satu alat formulasi pengambilan keputusan serta untuk menentukan strategi yang ditempuh berdasarkan kepada logika untuk memaksimalkan kekuatan dan peluang, namun secara bersamaan dapat meminimalkan kelemahan dan ancaman (Ikhsan dan Aid, 2011).

\section{Faktor Internal}

\section{Kekuatan (S)}

1. Kecamatan Medan Marelan merupakan salah satu sentra pertanian yang berada di Kota Medan sehingga tidak jauh dari pusat pasar.

2. Keadaan tanah pertanian Kecamatan Medan Marelan yang subur, memungkinkan untuk kegiatan usaha tani sayur.

3. Kegiatan usaha tani sayur yang dilakukan oleh pertani merupakan mata pencaharian yang telah turun temurun sehingga petani memiliki pengalaman yang banyak dalam kegiatan usaha tani sayur tersebut.

4. Tersedianya penyuluh yang dapat membantu petani dalam kegiatan usaha tani.

5. Terdapatnya kelompok tani dan koperasi pertanian sebagai wadah petani untuk meningkatkan daya saing.

6. Tersedianya pasar sayur yang khusus di bangun pemerintah Kota Medan di Kecamatan Medan Marelan untuk meningkatkan daya saing petani.

\section{Kelemahan (W)}

1. Kondisi iklim yang tidak bisa di prediksi lagi dan musim kemarau panjang menyulitkan petani dalam menyediakan air yang cukup untuk lahan pertanian.

2. Keberadaan Kelembagaan yang masih belum optimal.

3. Ketidakpercayaan petani pada kualitas benih bersubsidi yang diberikan pemerintah.

4. Sebagian petani juga tidak percaya dengan kinerja penyuluh pertanian lapangan.

5. Kegiatan pertanian yang masih dilakukan secara konvensional.

6. Keterbatasan petani dalam memperoleh bantuan permodalan usaha tani.

7. Manajemen keuangan dan cara pandang petani terhadap kegiatan agribisnis masih belum berkembang maju.

8. Ketergantungan petani yang tinggi dengan pedagang pengumpul (agen sayur).

9. Pemahaman petani yang masih rendah pada konsep pentingnya koperasi pertanian

\section{Faktor eksternal}

\section{Peluang (O)}

1. Permintaan konsumen terhadap sayuran semakin meningkat baik dikonsumsi untuk makanan pelengkap lauk pauk maupun untuk minuman seperti sayuran Sawi manis.

2. Implementasi MEA menyebabkan akses petani terhadap pasar global menjadi tidak sulit. 
3. Produksi sayur petani memiliki kualitas untuk di pasarkan pada pasar modern.

4. Kecamatan Medan Marelan pada tempat tertentu bisa di jadikan kawasan wisata hortikultura.

\section{Tantangan (T)}

1. Implementasi dari MEA yang menyebabkan warga asing bisa berjualan sayur dengan bebas di kota Medan.

2. Tingginya kondisi alih fungsi lahan dari sektor pertanian menjadi pemukiman.

3. Lembaga keuangan yang memberikan pinjaman dengan tingkat pengembalian yang tinggi sehingga menyulitkan ekonomi petani sayur.

4. Berkurangnya jumlah petani sayur sehingga tingkat serangan hama tanaman menjadi tinggi.

5. Motivasi petani yang masih rendah dalam memanfaatkan kegiatan kelompok tani dan koperasi pertanian.

6. Tingkat biaya kebutuhan hidup yang tinggi sementara pendapatan petani tidak dalam sebulan sekali tetapi terdapat masa tanam sampai perawatan.

\section{Strategi SWOT}

\section{Strategi S - O}

1. Meningkatkan produktivitas petani melalui kegiatan penyuluhan dan pelatihan sehingga produksi sayur yang dihasilkan berdaya saing.

2. Meningkatkan kemampuan kelembagaan petani dengan menjalin kerjasama yang erat antar petani, pemerintah dan agen.

3. Meningkatkan daya saing petani dengan mengembangkan koperasi agribisnis.

4. Mengembangkan agribisnis petani dengan memanfaatakan pasar sayur yang di sediakan pemerintah kota medan.

5. Meningkatkan produktivitas petani dengan

\section{Strategi W - O}

1. Membangun wadah klinik pertanian untuk menanggulangi penyakit tanaman dan keterbatasan obat-obatan pertanian.

2. Meningkatkan peran kelembagaan pemerintah dalam mensosialisasikan tentang peran koperasi agribisnis dan manfaat koperasi dalam melindungi tingkat harga sayuran.

3. Pengembangan peran koperasi agribisnis sebagai lembaga ekonomi dan pasar yang membantu petani sayur untuk memiliki ketersediaan modal untuk berusaha tani dengan teknologi pertanian.
4. Pengembangan peran koperasi agribisnis yang bisa meningkatkan pengetahuan usaha tani sayur petani dengan keaktifan petani dalam kegiatan penyuluh pertanian.

5. Pengembangan peran koperasi agribisnis untuk mengembangkan agribisnis organic dengan penerapan GAP/SOS pada petani.

Strategi $\mathrm{S}-\mathrm{T}$

1. Meningkatkan kualitas sayuran dalam menghadapi persaingan pasar domestic dan non domestic dengan meningkatkan partisipasi petani dalam pelatihanpelatihan sehingga wawasan petani yang mencerminkan sumberdaya manusia yang berkualitas meningkat.

2. Pengembangan koperasi agribisnis untuk menjembatani petani dengan pedagang pengumpul (agen) sehingga terbangun hubungan kemitraan yang saling menguntungkan.

3. Pengembangan koperasi agribisnis sebagai lembaga penyedia modal bagi petani

Strategi W - T

1. Pengembangan koperasi agribisnis untuk meningkatkan kemampun, kemandirian dan kesejahteraan petani.

2. Pengembangan koperasi agribisnis untuk memberikan motivasi bagi petani dalam meningkatkan pengetahuan teknologi pertanian.

3. Pengembangan koperasi agribisnis untuk mengoptimalkan peran kelompok tani.

4. Membuat perencanaan, pengorganisasian, pelaksanaan dan pengontrolan terhadap pengembangan koperasi agribisnis.

\section{Perumusan Model Peningkatan Daya Saing Petani Sayur melalui Implementasi The House Model}

Hasil analisis SWOT tersebut selanjutnya digunakan untuk merumuskan konsep The House Model yang menggambarkan harapan suatu organisasi menjadi suatu tindakan yang direpresentasikan pada sebuah gambar berbentuk rumah dengan atap, pilar dan pondasinya. Menurut Gasperz (2003), atap rumah merupakan visi organisasi yaitu suatu pernyataan menyeluruh tentang gambaran ideal yang ingin dicapai oleh organisasi untuk masa yang akan datang. Visi yang diperoleh dari analisis SWOT adalah; "Dengan Koperasi Agribisnis petani produktif dan berdaya saing". Selanjtunya dilakukan perumusan pondasi untuk mencapai visi yang telah di tetapkan. Adapun gambar struktur The House Model sebagaimana pada gambar 3 . 


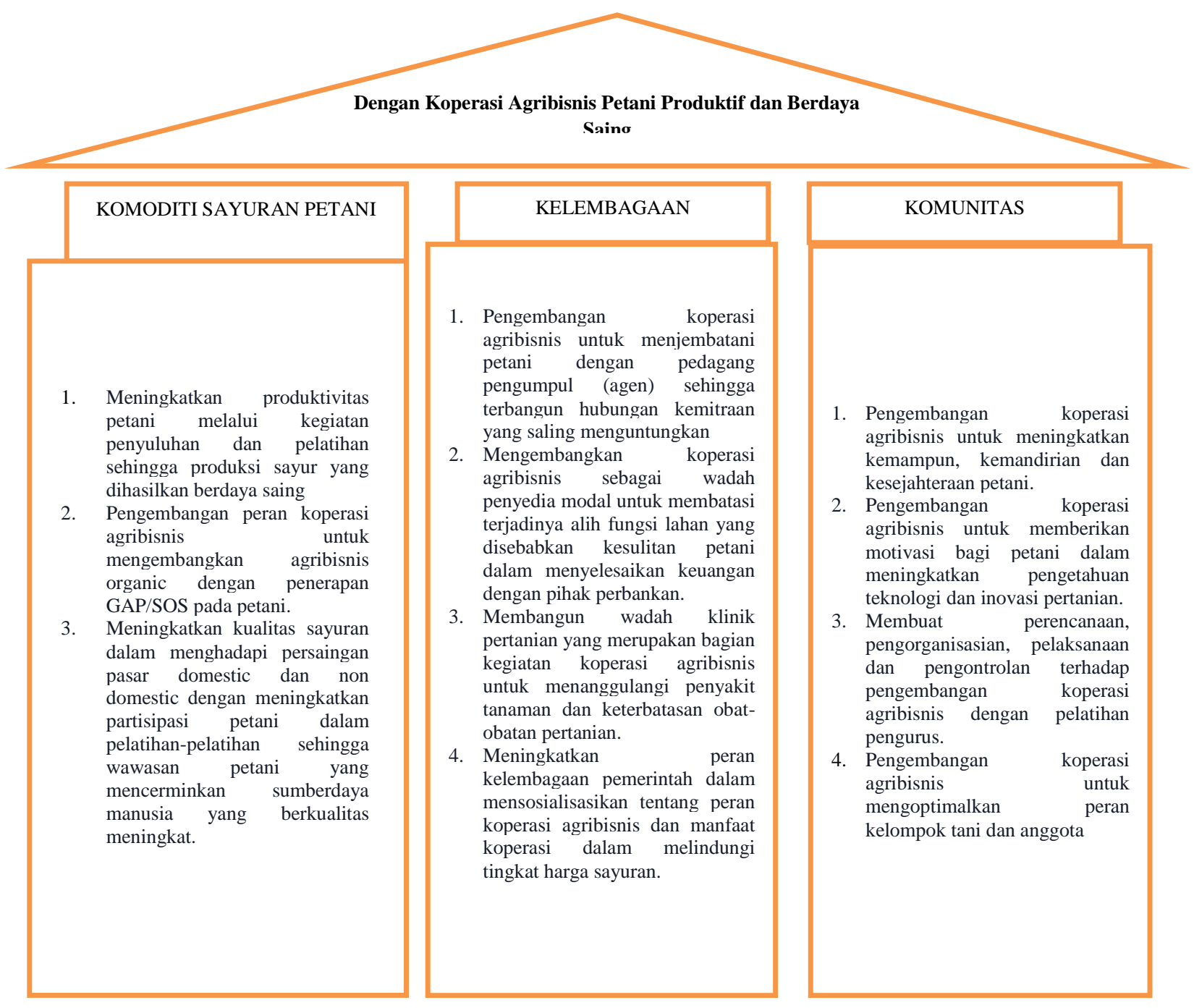

Upaya peningkatan produktivitas petani yang berdaya saing oleh pemerintah Kota Medan

Hasil dari The House Model menunjukkan bahwa untuk mencapai peningkatan daya saing petani di Kecamatan Medan Marelan, menggunakan beberapa alternative strategi yang bisa digunakan sebagaimana yang terdapat pada aspek pondasi yang merupakan kegiatan pendukung untuk mencapai visi yang telah ditetapkan. Adapun implikasi manajerial dari hasil yang diperoleh menunjukkan bahwa dalam upaya peningkatan daya saing petani sayur terdapat tiga aspek strategi yang harus dikembangkan yaitu;

1. Aspek Komoditi Usaha tani Sayur Petani Kecamatan Medan Marelan

Untuk meningkatkan daya saing petani Kecamatan Medan Marelan, maka hal yang pertama di perhatikan adalah produktivitas petani. Adapun produktivitas petani akan meningkat apabila petani aktif dalam kegiatan penyuluhan dan pelatihan. Sebagaimana penelitian Hilvan Mahani, Uzman (2013) bahwa peningkatan pelatihan petani akan meningkatkan kemampuan, kemandirian, dan kesejahteraan kelembagaan petani. Dengan aktifnya petani pada kegiatan penyuluhan pertanian, maka petani mengetahui bagaimana implikasi dari kebijakan pertanian sehingga petani akan selalu memiliki pemikiranpemikiran baru dan mampu membuat keputusan yang tepat untuk kegiatan usaha taninya.

Hanafie, Rita (2010) mengemukakan bahwa peningkatan mutu petani dalam kegiatan pelatihan dan penyuluhan tidak hanya bersifat teknis dan fisik saja, tetapi juga bersifat mental dan berhubungan dengan keterampilan manajemen. Contohnya dengan adanya sosialisasi yang telah digerakkan pemerintah terkait dengan penerapan Good Agriculture Practices (GAP). Petani Kecamatan Medan Marelan yang produktif akan mampu bersaing pada pasar global dengan menghasilkan produksi sayur yang bernilai tinggi yaitu 


\section{MODEL PENINGKATAN DAYA SAING PETANI}

dengan menerapkan budidaya pertanian yang baik dan benar sebagaimana dikenal dengan istilah GAP tersebut. Komoditi holtikultura khususnya sayuran memiliki potensi yang besar untuk dikembangkan dengan program GAP. Hal ini memperhatikan bahwa semakin tinggi permintaan konsumen terhadap sayursayuran organic.

\section{Aspek Kelembagaan}

Kelembagaan merupakan aspek yang berhubungan langsung dengan lingkungan petani. Kelembagaan memegang peranan penting dalam mempengaruhi tingkah laku petani sebagai individu, kelompok, dan masyarakat. Kelembagaan juga aspek yang berperan dalam memberikan perubahan pada petani baik perubahan cara berfikir dan perubahan tingkah laku. Hal pertama yang perlu diperhatikan adalah bagaimana merubah cara berfikir petani terhadap koperasi dan kelompok tani. Dalam hal tersebut petani harus memahami bahwa koperasi dan kelompok tani bukan hanya berperan sebagai fasilitator untuk memperoleh berbagai subsidi pertanian dari pemerintah. Lebih jaun, petani diberikan pemahaman tentang perlunya koperasi agribisnis yang berperan untuk melindungi petani dari tingkat harga sayur. Dan akan memberikan posisi tawar petani pada pemasaran produk sayur mereka. Disamping itu juga sebagai penyedia modal sehingga kasus petani kehilangan lahan dan tempat tinggal untuk menyelesaikan permasalahan keuangan

Peningkatan daya saing petani tidak terlepas dari peran agen yang sudah lama bermitra dengan petani. Untuk itu diperlukan koperasi agribisnis yang bisa menjembatani petani dengan pedagang pengumpul (agen) dalam membangun hubungan kemitraan yang saling menguntungkan. Dengan adanya kerjasama yang saling membangun maka antara petani dan agen terbangun relasi yang saling membutuhkan.

3. Aspek Komunitas

Aspek komunitas yang termasuk di dalamnya petani adalah aspek yang sangat penting. Dengan memperhatikan potensi sumberdaya petani, maka pengembangan koperasi agribisnis mutlak untuk di laksanakan. Dengan pengembangan agribisnis akan mampu meningkatkan kemampuan, kemandirian dan kesejahteraan petani. Untuk itu diperlukan pelatian manajemen pengurus yang mengarah pada koperasi agribisnis yang memiliki tiga elemen penting yaitu; memihak (targeting), mempersiapkan (enabling), dan melindungi (protecting).

\section{KESIMPULAN}

Kondisi problematis agribisnis sayur di Kecamatan Medan Marelan dapat diidentifikasi dari beberapa aspek yaitu; problematic pengadaan dan penyaluran sarana produksi pertanian, problematic kegiatan produksi (budidaya usaha tani sayur), dan problematis pemasaran. Pada problematic pemasaran juga diketahui bahwa terdapat empat struktur rantai pasok produksi sayur petani Kecamatan Medan Marelan. Model peningkatan daya saing petani sayur dapat dilaksanakan dengan memperhatikan aspek faktor internal dan eksternal yang selanjutnya dapat ditetapkan sebuah visi dalam peningkatan daya saing petani yaitu; "Dengan Koperasi Agribisnis Petani Produktif dan Berdaya Saing". Adapun aspek yang perlu dilaksanakan untuk mewujudkan visi tersebut adalah aspek komoditi sayur petani, aspek kelembagaan dan aspek komunitas.

\section{DAFTAR PUSTAKA}

Anwar, A dan Setia Hadi. 1996. Perencanaan Pembangunan Wilayah dan Perdesaan. Prisma No. Khusus 25 Tahun 1971-1996. LP3ES. Jakarta.

Astuti R, Marmin, Poerwanto R, Machfud, Arkeman Y. 2010. Kebutuhan dan Struktur Kelembagaan Rantai Pasok Buah Manggis (Studi Kasus Rantai Pasok di Kabupaten Bogor). Jurnal Manajemen Bisnis.3 (1):99 - 115.

Basri. Y.Z., 2003, Pemberdayaan Ekonomi Masyarakat Pedesaan, dalam Usahawan Indonesia No 03/TH.XXXII Maret 2003, Lembaga Manajemen FE-UI, Jakarta: halaman 49-55

Gasperz, Vincent. 2003. Sistem Manajemen Kinerja terintegrasi. Balanced Scorecard dan Six Sigma untuk Organisasi bisnis dan pemerintah. Jakarta. PT. Gramedia Pustaka Utama.

Gilarso, T. 1994. Pengantar Ilmu Ekonomi Bagian Mikro. Kanisius, Jakarta

Hanafie, Rita. 2010. Pengantar ekonomi Pertanian. Andi offset. Yogyakarta.

Hilvan Mahani, Uzman. 2013. Strategi Peningkatan Daya SAING Petani Komoditas Kentang Melalui Analisis Beban Kerja. Skripsi. Institut Pertanian Bogor.

Ikhsan S, aid 2011. Analisis SWOT untuk merumuskan strategi pengembangan komoditas Karet di Kabupaten Pulang 
Pisau, Kalimantan Tengah. Jurnal Agribisnis pedesaan. 1 (3);166-177

K.zakaria. Amar. 2010. Program Pengembangan Agribisnis Kedelai Dalam Peningkatan Produksi dan Pendapatan Petani.

http://pustaka.litbang.deptan.go.id/pub likasi/p3294104.pdf.

Nazir, Moh. 1999. Metode Penelitian. Ghalia. Jakarta

Porter. 1990. The Competitive Advantage of Nations. Harvard Business Review
Putong, Iskandar. 2005. Teori Ekonomi Mikro. Mitra Wacana Mulia. Jakarta

Saptana, Sunarsih dan K.S Indraningsih. 2006. Mewujudkan Keunggulan Komporatif menjadi Keunggulan Kompetitif melalui Pengembangan Kemitraan Usaha Hortikultura. Forum Penelitian. Agro - Ekonomi.

Soekartawi.2002.Prinsip-prinsip Dasar Ekonomi Pertanian. PT. Raja Grafindo. Jakarta. 